August 2009

\title{
The Albright-Cohen Report: From Realpolitik Fantasy to Realist Ethics
}

Henry C. Theriault

Follow this and additional works at: https://digitalcommons.usf.edu/gsp

\section{Recommended Citation}

Theriault, Henry C. (2009) "The Albright-Cohen Report: From Realpolitik Fantasy to Realist Ethics," Genocide Studies and Prevention: An International Journal: Vol. 4: Iss. 2: Article 11.

Available at: https://digitalcommons.usf.edu/gsp/vol4/iss2/11

This Articles is brought to you for free and open access by the Open Access Journals at Digital Commons @ University of South Florida. It has been accepted for inclusion in Genocide Studies and Prevention: An International Journal by an authorized editor of Digital Commons @ University of South Florida. For more information, please contact digitalcommons@usf.edu. 


\title{
The Albright-Cohen Report: From Realpolitik Fantasy to Realist Ethics
}

\author{
Henry C. Theriault \\ Worcester State College, Worcester, MA
}

The Genocide Prevention Task Force's Preventing Genocide: A Blueprint for U.S. Policy Makers (the Albright-Cohen Report) has been touted as a comprehensive proposal for significantly improving the United States' response to genocide and other mass violence in foreign regions. ${ }^{1}$ The report recommends various new initiatives, committees and groups, procedures, and resource allocations to support this goal. It also calls for increased attention to genocide at every level of the US government, from the president on down. The assumption is that if our leaders and others in government take genocide more seriously as an ongoing threat, and if effective institutional structures, processes, and resources are put in place, these will be used to prevent or intervene against genocide and other mass atrocities. At its most basic level, the report seeks to change the practical details and conceptual elements of the United States' relationship to genocide, from what the report presents as relative indifference to active, productive engagement.

\section{The Report's Statement of the Problem}

Crucial to such an exercise, of course, is an assessment of the current relationship. According to the report's authors, genocide happens in unstable societies, often in postconflict situations or when contending forces, perhaps split along ethnic or other identity lines, vie for power in a new or a "failed" state. In addition, the US government is fully external to historical examples of genocide as presented in the report, and to potential genocides as discussed therein. Genocide is seen as a discrete dynamic that happens somewhere else, and the challenge is for the United States to overcome its external positioning in order to intervene before or during the execution of a given genocide. It might use a number of options, from diplomatic negotiation and targeted aid to economic sanctions and military action.

According to the report, there are three main problems with the United States' past relationship to genocide. First, the United States has often failed to recognize that what was occurring was genocide, as in the case of Rwanda. Second, even when it has recognized the potential for genocide or that genocide was under way, the United States has failed to take preventative steps or to intervene-in some instances through a lack of political will and in others because of a perceived conflict with overriding US interests. Third, prevention and intervention efforts, when made, have typically been inadequate or inconsistent. The challenge, then, is correctly to identify, hopefully well before situations are critical, societies in which genocide might occur or in which it is occurring, and to respond with diplomatic efforts, development projects, political initiatives, military intervention, and/or other tools to prevent genocide from occurring or to stop it once it has begun.

Henry C. Theriault, "The Albright-Cohen Report: From Realpolitik Fantasy to Realist Ethics." Genocide Studies and Prevention 4, 2 (August 2009): 201-210. (C) 2009 Genocide Studies and Prevention. doi: 10.3138/gsp.4.2.201 


\section{Evaluation}

Is this general appraisal of the threat of genocide in the world and of problems with past US responses accurate? To some extent, perhaps; but it includes a number of problematic elements.

First, it is not true that genocides occur today, or have occurred in the past, only in fragmented, "failing" states. While this might have been the case in the former Yugoslavia, it was not true in Rwanda, which had stable borders and a fixed political structure that lent itself to a highly organized, carefully calculated, precisely executed, and tightly controlled genocide. ${ }^{2}$ Similarly, while Sudan has seen internal division and conflict for decades, there is every indication that the genocidal assaults in Darfur are managed by a government solidly in control of what happens within its borders. ${ }^{3}$ If we extend the analysis to other cases, we find, for instance, that genocidal violence in East Timor began in the 1970s, when the Indonesian government was undeniably stable and powerful and had such control over the situation that it was able to use local paramilitary groups systematically as tools of genocide. ${ }^{4}$ The Herero Genocide, the Armenian Genocide, the Ukrainian Genocide, the Holocaust, the Guatemalan Genocide, the Cambodian Genocide, ${ }^{5}$ and genocides of indigenous peoples in the Amazon, ${ }^{6}$ among others, were perpetrated by fixed, established states with governments in firm control. While tensions within states have certainly contributed to genocide, similar and worse tensions exist in all sorts of other states without producing genocide. Indeed, historically, the "failed state" view of genocide at best captures one type among many. By focusing on that particular kind of case, the Albright-Cohen Report has produced recommendations that may well not apply to other contexts and thus cannot engage other kinds of genocides adequately. For instance, development aid will presumably not be a good method of intervention when the perpetrator state is economically strong or supported by economically strong outside actors. Further, this approach discounts precisely the kinds of genocides in which the United States and other great powers are typically involved.

Second, and relatedly, it is not the case that the United States failed to act, in the cases discussed in the report, because its leadership did not realize that genocide or other mass violence was occurring. We know very well that the US government understood that genocide was occurring in Rwanda, in the former Yugoslavia, and in other contexts. ${ }^{7}$ Some cases have dragged on genocidally for years, as in Sudan, even after recognition by the US government that genocide was occurring. ${ }^{8}$ Given this fact, the report's emphasis on early warning seems designed to obscure the fact that US leadership_including Madeleine Albright herself, during the Rwandan Genocide $^{9}$ - has consistently failed to intervene as a result of conscious, explicit policy decisions made with full awareness of the situations in question and of the consequences of inaction.

Third, the implicit assumption that the United States has been or will be disconnected from past and future genocides is false. The United States has, in fact, been intimately involved in a number of genocides, even in recent years. This not only means that, since key decision makers in the US government have been well aware of cases such as East Timor and Guatemala while they were unfolding-because we were complicit in them-the concern about early warning is irrelevant, but also calls into question a further element of the report's framework. Albright and Cohen's claim, in their Foreword, that genocide is "a crime that threatens not only our [US] values, but our national interests" (ix)—a view repeatedly echoed in the report-is, historically, 
simply not true. For instance, the United States provided weapons, logistical support, diplomatic cover, political support, and/or other support for Indonesia's genocide of East Timorese, ${ }^{10}$ Guatemala's genocide of Mayans, ${ }^{11}$ the 1965 Indonesian genocide of so-called Communists, ${ }^{12}$ Saddam Hussein's genocide of Kurds, ${ }^{13}$ and probably the Bangladesh Genocide, to name just a few cases. If the focus is broadened to mass atrocity as well, we must include substantial military and diplomatic support for Turkey's mass human-rights violations against Kurds; Israel's mass human-rights violations against Palestinians; the direct US involvement in the assassination of the democratically elected Salvador Allende in Chile on 11 September 1973, the installation in his place of mass human-rights abuser Augusto Pinochet, and subsequent support for Pinochet's regime; support for El Salvador's brutal government in the 1980s; support for the Shah of Iran; and many others. In short, it has been consistent US policy to support genocide and related mass violence against innocent targets whenever such support has been perceived to serve some kind of (usually military or corporate) US interest.

The United States has even retroactively involved itself in genocide on the side of the perpetrator state. While during the Armenian Genocide the record of US diplomats, led by Henry Morgenthau and including such figures as Leslie Davis and Jesse B. Jackson, was exemplary, ${ }^{14}$ it is striking that the then secretary of state, Robert Lansing, and others maintained a pro-Turkish policy ${ }^{15}$ that has been embedded in the State Department and in US policy ever since. The US government, with the exception of some Congressional leaders, has strongly supported the Turkish government's denial of the Armenian Genocide. It is noteworthy that both Albright and Cohen have actively attempted to prevent US recognition of the Armenian Genocide, ${ }^{16}$ a fact that calls into question their credibility on genocide issues generally. Reflecting their activities against recognition of the Armenian Genocide is the fact that the report contains no explicit reference to an "Armenian Genocide": what happened to Armenians is mentioned in only three places in the report, where it is characterized as a "mass atrocity" (19, 94), "forced exile" (19), and an "atrocity" (56); the report thus specifically avoids use of the technically correct and politically and ethically important term "genocide" for this heavily denied case. Rather than taking a stand against denial, with all that that would do for prevention of future genocides (helping to change the climate of denial to make it less likely that denial of ongoing cases will be accepted), the report itself, in this dimension, becomes a further obstacle to an appropriate US response to genocide.

The report consistently ignores the foregoing issues, instead presenting the United States' relationship to genocide as one of mistaken inaction and unfortunate indifference. For instance, the US "failure" in Rwanda, according to the report, was "that the attention of senior policy makers was distracted from Rwanda in 1994 by other crises unfolding at the same time in Somalia, Bosnia, and Haiti" (2). There is no mention that nothing substantive was done about Bosnia, either; moreover, this statement completely disregards the ample evidence that US leaders intentionally denied that the situation in Rwanda was a genocide, despite their knowledge to the contrary in the early stages, in order to avoid intervening. ${ }^{17}$ The United States has been far from indifferent to genocide. At a number of points, the authors, while pointing out that the United States has not been perfect, claim that on balance, with respect to genocide, the United States has done more good things than bad. This is simply not the case. Kenya seems the main "good case" cited, and what is presented as successful US intervention is mentioned many times $(2,20,21,45,62,68,71,94)$, 
almost as if repeated mention of this one situation will somehow multiply into a whole history of positive US actions that, in fact, have not taken place. To support the claim that the United States has a good track record of prevention and intervention, the report states that

an honest accounting shows that the United States has much to its credit in these matters-from mobilization for total war to defeat the genocidal Nazi regime, to lesser military campaigns aimed at halting mass atrocities in Bosnia and Kosovo, to the enforcement of a no-fly zone in Iraq to protect that country's Kurdish population from Saddam Hussein's regime. In addition to military measures, the United States has been active diplomatically, for example in Kenya in early 2008, to prevent situations posing the danger of mass atrocities from escalating. (94)

This is followed by a caveat:

While the United States has much to its credit, candor demands acknowledgment that it has not always lived up to the aspirations codified in the Genocide Convention, the Universal Declaration of Human Rights, and the UN Charter-or the principles of our own Declaration of Independence, which insists that all people are endowed first of all with an inalienable right to live. Too often, the United States has failed to act in a timely fashion and has engaged in counterproductive finger-pointing and denial. (94)

These statements skew the reality of the particular cases (surely no one believes that World War II was actually fought to stop the Holocaust, especially given that the Allies would not spare the resources or make the effort to bomb railways used to transport victims to death camps) and understate and obscure the problem dramatically. The report becomes outright hypocritical when, following these statements, we discover that other countries do in fact "turn a blind eye to atrocities," sometimes as "a direct result of their own complicity" (95): this obvious point is never made about the United States, yet is considered valid for other societies.

It should be noted that, where genocide and other mass violence do result from destabilization of a society, the United States has frequently been involved in this destabilization as well. Perhaps the most telling case is the bombing of Cambodia, which (though this point is still debated) by many accounts played a role in the later genocide. $^{18}$

\section{The Fundamental Problem}

Yet even the foregoing is only the tip of the iceberg of the US relationship to genocide. To understand that relationship, it is crucial to recognize that the United States itself was founded territorially on genocide of Native Americans, as a matter of longstanding, centralized state policy as well as of attitudes and actions within civil society and popular culture. While a comprehensive account of US genocidal action against Native Americans and its embedding in our popular and political culture and institutions is beyond the scope of this commentary, certain elements pointing to a general account can be conveyed.

First, the extermination of Native Americans through direct killing, destruction of food supplies, forced deportation under deadly conditions, and other means-all of which fit the definition of genocide given in the Convention on the Prevention and Punishment of the Crime of Genocide-were government policy from the Revolutionary War at least until 1890. This was true of federal as well as state and local governments-for instance, through the infamous state "scalp bounties" used to pay private contractors to exterminate Native Americans deemed "hostile," which ended up supporting the murder of many "pacified" Native Americans. While not every 
Native American group was subjected to genocide, the overall effect of US policies and of governmental and non-governmental actions organized around the ideology of Manifest Destiny and its predecessor forms was the genocidal destruction of Native American societies. On the order of 10 million Native Americans resided in what would become the continental United States prior to European contact; only 237,000 lived on that territory by 1900 . Even recognizing that a portion of the destruction occurred before the formation of the United States as an independent nation, the role of the United States was significant and generally determinative.

Second, even after the end of direct genocide with the Massacre of Wounded Knee in 1890, genocidal policies continued in the twentieth century against the residual indigenous population (largely captive on reservations by this point), most notably the brutal forced assimilation of Native American children in Christian boarding schools and the forced sterilization of Native American women. Where Native American political organizing has threatened the land and other gains of genocide, the US government has sponsored or countenanced direct violence, for instance with the assassinations of more than 100 American Indian Movement leaders and their family members in the early 1970 s. $^{19}$

What is particularly striking and American about this genocidal process is the extent to which it was decentralized and dependent on individual initiative within an overall state-sponsored framework. Groups of settlers as private citizens, paramilitary groups, and other groupings were important elements in the destruction of Native Americans. Thus, Native American genocides were not simply top-down affairs but involved a willing broader US population. The evidence of widespread approval for genocide is ample, as for instance in Wizard of $\mathrm{O} z$ author L. Frank Baum's comments in the Aberdeen Saturday Pioneer on 20 December 1890, following Wounded Knee:

The nobility of the Redskin is extinguished...The Whites, by law of conquest, by justice of civilization, are masters of the American continent, and the best safety of the frontier settlements will be secured by the total annihilation of the few remaining Indians. Why not annihilation? Their glory has fled, their spirit broken, their manhood effaced; better that they should die than live the miserable wretches they are. ${ }^{20}$

What does all of this mean? It means that genocide is at the core and foundation of American history and national formation, and that its influence on policy decisions today cannot be avoided. If most of us, in essence, "forget" the past treatment of Native Americans, that treatment is part of the organizational memory of US political, military, and cultural policies, practices, and institutions. Until this relationship to genocide is changed, our future engagements with genocide will be informed and compromised by it. Just as our perpetration of genocide against Native Americans has grounded our support for the other genocides with US complicity discussed aboveparticularly where the victims have been indigenous Americans, as in the case of Guatemala-the cumulative effect of this bedrock and what we have built on it will continue to provide powerful impetus for US indifference to and complicity in genocide around the globe. And, it is little wonder that so many in the US government, including the State Department, see nothing wrong with the Armenian Genocide and fully support Turkey in its denial: the role of the Armenian Genocide in the formation of the Turkish Republic is in some ways analogous to that of Native American genocides in the formation of the post-Revolutionary United States through territorial expansion. It is little wonder we have countenanced genocides around the globe. 
The Albright-Cohen Report, in failing to engage this central issue of US identity, cannot offer meaningful recommendations on how to motivate an appropriate US response to genocide, no matter how many committees, administrative shifts, trainings, and resource allocations it proposes. The problem is not a technical challenge of how to develop successful mechanisms of prevention and intervention against genocide, nor of how to energize US governmental and popular sentiment to care about genocide as an issue to which we are otherwise indifferent. The problem is how to change the deep relationship between the United States and genocide.

\section{Diplomatic, Military, and Other Intervention}

The authors of the report recognize that there will be suspicion of US diplomatic, military, and aid-oriented attempts to prevent or stop genocide. However, they fail to engage this concern in a serious way. For instance, while they recognize that some such suspicion might come from the fallout of the Iraq War, they consider it mainly "a by-product of the U.S. position as the world's leading military power" and "suspicion of U.S. ambitions to transform other societies through such long-standing policies as democracy promotion" (95-96). Clearly, the problem is not simply the fact that the United States has great military power but, rather, how we have used that power. In fact, we have used military power aggressively from the 1836 Mexican War through the Spanish-American War and the Vietnam War; we have used military intervention in many Latin American countries solely to promote our own interests from the early twentieth century on, including some of the cases already mentioned above; and so on. The suspicion of US militarism is valid, however much, from the vantage point of our own self-interest and national self-promotion, we might see the use of military violence to secure the desired goals of US political and economic elites as legitimate. Similarly, the idea of "democracy promotion," which the authors of the Albright-Cohen Report uncritically accept at face value, is deeply problematic, as we have supported many repressive regimes around the world in the name of "freedom" 21 and even claimed some non-democratic states, such as the contemporary Turkish Republic, as democracies because of their utility in advancing our interests. US-led international development efforts, most notably by the US Agency for International Development, the International Monetary Fund, and the World Bank, also have questionable histories. They have for years been widely criticized for imposing on countries desperate for help after being devastated by colonial exploitation, and in the face of the new inequalities of globalization, conditions that have destabilized their societies and driven local populations into abject poverty, conditions that have mainly served the interests of US-based multinational corporations.

This problem is compounded by the continued operation of such institutions and initiatives as the School of the Americas, which has been shown to train foreign soldiers and others in the abuse of human rights and many of whose graduates have been identified as major human-rights abusers in their home countries in Latin America. ${ }^{22}$ It is difficult to understand how the United States can promote human rights and try to prevent genocide on the one hand while clearly promoting abuse of human rights and systematic state violence on the other.

In the absence of a serious engagement of these issues and changes in the political culture and policies that have produced them, US intervention efforts-even those that are, in the moment, well-intentioned-will inevitably be identified with this broader, darker history and all too easily co-opted for continuation of that history. 


\section{A Key Omission}

In the $100+$ pages of the report, "rape" and "sexual violence" are mentioned a total of three times (xvi, xx, 49). Yet, as a growing literature has shown, violence against women is very often a central component in genocide and related mass violence. In a recent paper, in fact, I argued that sexual violence against women has historically been a key motivating factor for genocide. ${ }^{23}$ What is more, gender violence as an element of genocide reflects deep structural features that are shared broadly across societies. If gender violence is a core component of genocide-the Armenian, Rwandan, and Bosnian cases are particularly well-documented in this respect-then prevention of genocide requires engaging the foundations of gender violence, which themselves go beyond specific features of a given society. At the very least, the report should include detailed analysis of this issue and recommendations on how to deal with this aspect of genocide and its likely causal role. Instead, not a single recommendation in the report addresses this central issue.

\section{Alternative Recommendations}

I have asserted above that the Albright-Cohen Report sidesteps or omits entirely the core problems the United States faces in preventing and intervening against genocide globally. My main objections are these:

(1) The report mistakes a subset of genocides ("failed state" genocides) for the form of all genocides; even if its recommendations can improve the response to this form, they might well not address other forms.

(2) The report fails to conceive accurately the true relationship of the United States to genocide.

(3) The report fails to take seriously the active abuse of what it proposes as key methods of genocide prevention and intervention.

The first problem could be addressed in part through a more comprehensive approach to the various historical cases of genocide and a better use of the ample scholarly literature on the range of forms it takes. However, the particular view of genocide advanced in the report functions ideologically to prevent the raising of uncomfortable questions about US foreign and domestic policy: it maintains genocide as something distant and external, something particular to unstable postcolonial states in Africa, the odd aberrational European "failed state", Asia, and so on. Thus, the problem is not simply an academic one, and its correction requires engagement with problem 2 . For problems 2 and 3, I propose the following as prerequisites to any further policy recommendations.

- Recommendation 1: An independent government office should be created to evaluate all significant diplomatic, military, and related policies, actions, alliances, foreign aid, foreign weapons and other resource distributions, and so on, to determine their potential impact with respect to genocide: What are the potential long-term consequences, and how might these contribute to increased risk of genocide or other mass violence? How might a policy or action decrease the potential for genocide? What risks and uncertainties are involved? What can be done, and how difficult (expensive, complex, dangerous, etc.) will it be to do if the policy or action, once implemented, begins to increase the risk of genocide or other mass violence? To be effective, these evaluations must be subject to public scrutiny, where state secrets are not sufficient to outbalance the interest in good decision making, and to Congressional oversight. 
- Recommendation 2: Such institutions as the School of the Americas/WHINSEC should be closed, both to decrease the number of trained human-rights abusers who are potential perpetrators of mass violence worldwide and to increase the credibility of future US prevention and intervention efforts.

- Recommendation 3: Through a comprehensive education initiative and policy modifications, US government institutions that promote genocide and other mass violence or hinder other governmental prevention and intervention efforts should be changed. For instance, US State Department personnel working with Turkey are often trained to deny the Armenian Genocide-for example, by attending workshops run by a prominent academic denier of the Armenian Genocide. ${ }^{24}$ Not only is inculcation of this falsification of history detrimental to Armenians, it also-from the perspective of a pragmatic politics of US interests-actually impedes the reality-based relationship with Turkey that is crucial to negotiating the complex dynamics of the ever-changing Middle East. What is more, this training fosters in the State Department an institutional commitment to genocide denial through which other regions might be interpreted, as well as making effective denial strategies and arguments readily available to those who wish to cover up other cases. This conceptual framework might well have played a role in the US government's disastrous denialist response to the Rwandan Genocide, for example. If the US government is to be committed to genocide prevention and intervention, ending denialist policies in its various institutions is crucial.

- Recommendation 4: The issue of sexual violence against women as tool of and motive for genocide must be given full weight and must be integrated explicitly into all US genocide-prevention and intervention efforts. Studies should be done to assess the correlation between sexual violence against women and increased risk of genocide.

- Recommendation 5: The US government, presumably through the Congress, should convene a wide-reaching and comprehensive US Genocide Truth and Responsibility Commission (USGTRC) to explore, through public testimony and documentation, the full history and implications of the United States' involvement with genocide. In addition to a thorough accounting of US genocidal participation, the USGTRC should promote an understanding of the role of genocide in the territorial and identity formation of the United States. The commission should also open up space for consideration of how contemporary US citizens can take responsibility for this history, in terms of relations with victim groups and of changes in national culture, political institutions and practices, foreign policy, and so forth.

Short of taking these steps, it is difficult to see how the United States can meaningfully increase its effectiveness in preventing and intervening against genocide. While the Albright-Cohen proposals might perhaps enable better intervention against a case here or there, they will not improve the overall US engagement with genocide and other mass violence in the vast majority of cases-and might in fact provide better cover for US complicity in or perpetration of future genocides.

\section{Notes}

1. Madeleine K. Albright and William S. Cohen, chairs, Preventing Genocide: A Blueprint for U.S. Policymakers (Washington, DC: Genocide Prevention Task Force, 2008), 
http://www.usip.org/genocide_taskforce/report.html (accessed 12 June 2009), xxi. Subsequent references appear parenthetically in the text.

2. See, e.g., Alison Des Forges, Leave None to Tell the Story: Genocide in Rwanda (New York: Human Rights Watch, 1999), http://www.hrw.org/legacy/reports/1999/rwanda/ (accessed 15 June 2009); Samantha Power, "A Problem from Hell": America and the Age of Genocide (New York: Basic Books, 2002); “The Triumph of Evil,” Frontline (Boston: PBS/WGBH, 1999).

3. Even the Report of the International Commission of Inquiry on Darfur to the United Nations Secretary-General (Geneva: United Nations, 2005), which concluded that genocide was not occurring in Sudan, recognizes that "government forces and militias conducted indiscriminate attacks, including killing of civilians, torture, enforced disappearances, destruction of villages, rape and other forms of sexual violence, pillaging and forced displacement, throughout Darfur ... on a widespread and systematic basis" (3). The report also details the close links between the government and Janjaweed militias. The Sudanese government has supplied weapons and other support, including salaries for militia members, and in many cases has directly ordered Janjaweed violence (34).

4. See, e.g., Matthew Jardine, East Timor: Genocide in Paradise (The Real Story) (Monroe, ME: Odonian Press, 1996).

5. On each of these cases, see, e.g., relevant entries in Israel W. Charny, ed., Encyclopedia of Genocide, vols. 1-2 (Santa Barbara, CA: ABC-CLIO, 1999).

6. See Gerard Colby and Charlotte Dennett, Thy Will Be Done: The Conquest of the AmazonNelson Rockefeller and Evangelism in the Age of Oil (New York: HarperCollins, 1995).

Though not specifically a work of genocide scholarship, this book highlights the coordination of state governments with a key corporate actor and evangelical organization in the destruction of indigenous groups in the Amazon region.

7. See Power, "A Problem from Hell."

8. Jim VandeHei, "In Break with U.N., Bush Calls Sudan Killings Genocide," Washington Post, 2 June 2005, A19. The pronouncement was made by President George W. Bush in 2005, but to date the United States has taken no substantive action to stop this genocide.

9. See Samantha Power, "Bystanders to Genocide," Atlantic Monthly, September 2001, 84-108.

10. Jardine, East Timor.

11. See, e.g., Global Exchange, "Guatemala: A Brief History," http://www.globalexchange.org/ countries/americas/guatemala/history.html (accessed 15 June 2009); and "Conclusions" in Guatemala-The Memory of Silence: Report of the Commission of Historical Clarification (commissioned by the United Nations), http://shr.aaas.org/guatemala/ceh/report/english/ conc1.html (accessed 15 June 2009), paras. 13-14 ("The Cold War, National Security Doctrine and the Role of the United States").

12. See Charny, Encyclopedia of Genocide.

13. See Power, "A Problem from Hell."

14. For example, see their reports on the Armenian Genocide as it occurred, in Ara Sarafian, comp., United States Official Records on the Armenian Genocide, 1915-1917 (Princeton, NJ: Gomidas, 2004).

15. Simon Payaslian, "The United States Response to the Armenian Genocide," in Looking Backward, Moving Forward: Confronting the Armenian Genocide, ed. Richard G. Hovannisian, 51-79 (New Brunswick, NJ: Transaction, 2003).

16. For examples of their long-time denialist activities see Emil Sanamyan and Nareg Seferian, "U.S. Told to Give Higher Priority to Genocide Prevention: Albright-Cohen Report Sidesteps Armenian-American Concerns," Armenian Reporter, 11 December 2008, http://www.reporter.am/go/article/2008-12-11-u-s-told-to-give-higher-priority-to-genocideprevention (accessed 15 June 2009). One of Albright's most striking acts was to sign a 25 September 2007 letter from eight former US secretaries of state to Nancy Pelosi, 
speaker of the US House of Representatives, strongly urging her to prevent House Resolution 106, recognizing the Armenian Genocide, from making it to the floor of the House for a vote. See "Turkey Enlists Former U.S. Secretaries of State," The Armenian Weekly, 29 September 2007, http://www.hairenik.com/armenianweekly/fpg09290702.htm (accessed 15 June 2009).

17. Des Forges, Leave None to Tell the Story; Power, "A Problem from Hell"; " The Triumph of Evil."

18. See, e.g., Taylor Owen and Ben Kiernan, "Bombs over Cambodia," The Walrus, October 2006, 62-69, http://www.walrusmagazine.com/articles/2006.10-history-bombing-cambodia/ (accessed 15 June 2009).

19. This analysis is drawn from the comprehensive and extremely well documented and well argued account of US genocidal acts against Native Americans in Ward Churchill,

A Little Matter of Genocide: Holocaust and Denial in the Americas, 1492 to the Present (San Francisco: City Lights, 1998).

20. Quoted ibid., 244-45.

21. There are many such examples, unfortunately. Obvious ones include the Shah of Iran, Anastasio Samoza in Nicaragua, Ferdinand Marcos in the Philippines, and Suharto in Indonesia.

22. Because of the bad reputation it had developed, in 2001 the School of the Americas was renamed the Western Hemisphere Institute for Security Cooperation (WHINSEC), though its mission and approach remain the same. For information on the School of the Americas/ WHINSEC's devastating impact on human rights in various Latin American countries, see the extensive documentation and analysis at School of the Americas Watch, http://www.soaw.org (accessed 15 June 2009).

23. Henry C. Theriault, "Rape as a Tool of Genocide or Genocide as a Tool of Rape?" (paper presented at the 8th Biennial Conference of the International Association of Genocide Scholars, Arlington, VA, 8 June 2009).

24. Namely Heath Lowry, Ataturk Professor of Ottoman and Modern Turkish Studies at Princeton University: http://www.princeton.edu/ nes/faculty_lowry.html (accessed 16 June 2009). Lowry is a well-known denier of the Armenian Genocide whose direct link to and proxy actions for the Turkish Embassy to the United States were documented and exposed in Roger W. Smith, Eric Markusen, and Robert Jay Lifton, "Professional Ethics and the Denial of the Armenian Genocide," Holocaust and Genocide Studies 9 (1995): 1-22. 